\title{
Growth Hormone Deficiency (GHD) from Birth to 2 Years of Age: Diagnostic Specifics of GHD during the Early Phase of Life
}

\author{
Amanda L. Ogilvy-Stuart \\ Rosie Hospital, Addenbrooke's NHS Trust, Cambridge, UK
}

\section{Key Words}

Fetus - Infant - Growth hormone - Insulin-like growth factor I. Growth hormone deficiency - Hypothalamicpituitary axis · Insulin-like growth factor binding protein

\begin{abstract}
The first 2 years of life represent a transition period when growth changes from predominantly growth hormone $(\mathrm{GH})$ independent to $\mathrm{GH}$ dependent. In the fetus, growth is influenced by genetic and environmental factors in addition to nutrition and growth factors including insulin. In infancy, nutrition remains an important determinant of growth. GH levels are high in mid-gestation and at birth, then fall sharply for the first few weeks and more slowly over the next few months reaching pre-pubertal levels by around the age of 6 months. GH deficiency (GHD) may present at birth with hypoglycaemia, micropenis or prolonged conjugated hyperbilirubinaemia. Although length at birth is usually within the normal centile ranges, post-natal growth failure can begin early and be profound.
\end{abstract}

Copyright (c) 2003 S. Karger AG, Base

\section{Growth Hormone in Fetal and Early Life}

Growth hormone $(\mathrm{GH})$ can be detected in the fetal circulation from 10 weeks of gestation [1], and concentrations of GH rise from 12 weeks to a peak in mid-gestation, when levels are higher than at any other time in life $(\sim 100 \mathrm{ng} / \mathrm{ml})$, and then fall towards term $[2,3]$. Animal studies have demonstrated that fetal GH secretion from the pituitary is pulsatile and under hypothalamic control [4] as well as negative feedback control linked to circulating insulin-like growth factor I (IGF-I) levels [5]. The fall of GH levels in late gestation may be related to rising endogenous IGF-I levels.

At birth, GH levels are high and pulsatile, with elevated baseline, mean and peak levels [6-10]. Pulsatile GH secretion has been described in both term [6-8] and preterm [6, 8-10] infants, with pre-term babies having higher pulse amplitudes but similar pulse frequency compared with term babies [6]. Estimates of pulse frequency have ranged between 2.5 and 9.9 per $12 \mathrm{~h}$ and may be greater in the first $48 \mathrm{~h}$ [10]. After the first 2 days of life, there is a decrease in pulse frequency, pulse amplitude and baseline levels [7].

Study of the influence of sleep on GH secretory patterns in the first 2 years of life has been hampered by lack of non-stressful sampling techniques. In older individu-

Dr. A.L. Ogilvy-Stuart

Neonatal Unit, Rosie Hospital, Addenbrooke's NHS Trust Cambridge, CB2 4AP (UK)

Tel. +44 1223 245151, Fax +44 1223217064

E-Mail amanda.ogilvy-stuart@addenbrookes.nhs.uk
Fax + 41613061234 E-Mail karger@karger.ch www.karger.com (c) 2003 S. Karger AG, Basel

Accessible online at:

www. karger.com/hre 
als, GH secretion is influenced by sleep-wake cycles, with slow-wave sleep triggering $\mathrm{GH}$ release $[11,12]$. Within the limitations of the sampling techniques, GH levels are not different between wake and sleep before 3 months of life. After 3 months, GH levels are significantly higher during sleep as a result of much lower levels when awake compared with during the first 3 months [13].

The high GH levels seen during the neonatal period may result from a lack of negative feedback from relatively low levels of circulating IGF-I [5]. The changes over the first few days may represent changes in the pituitary regulation of GH by somatostatin (SMS) and GH-releasing hormone (GHRH). Although both SMS and GHRH are present in the hypothalamus at birth, there are conflicting data regarding whether the pituitary responds to exogenous GHRH in the neonatal period $[14,15]$. In the neonatal rat, SMS increasingly inhibits spontaneous and GHRH-stimulated GH release over the first few weeks of life [16].

In the newborn infant, there is a relationship between GH pulsatility, feeds and insulin secretion [9]. A clear post-prandial rise in $\mathrm{GH}$, and the coincident pulses of $\mathrm{GH}$ and insulin, suggest that the stimulus for both may be related to feeds. The mechanism is unknown, but it may be associated with a direct effect of insulin, or to other feed-related secretagogues (such as changes in amino acids, or free fatty acids). A paradoxical rise in $\mathrm{GH}$ during hyperglycaemia has been observed in the first 6 days of life, and is most pronounced in pre-term infants [17]. It has been suggested that the increase in $\mathrm{GH}$ induced by a glucose load could be a signal for protein synthesis.

The role of the elevated levels of GH in the fetus and in infancy is unclear. Although GH receptors are present during fetal life [18], studies in animals [19] and human fetuses [20] suggest that GH does not play a major role in fetal growth. An alternative metabolic role for the high GH levels has been proposed [21, 22]. It may induce insulin resistance and thus protect the fetal brain from hypoglycaemia, whereas the lipolytic effects could provide alternative fuels for metabolism [22].

$\mathrm{GH}$ levels in the blood decline quite rapidly over the first 2 weeks of life, although elevated levels compared with older children and adults may still be apparent at 8 weeks of life $[1,21,23]$. The pattern of decline in GH levels over the first 2 years of life is shown in figure 1 [24].

GH-receptor mRNA is present in chondrocytes, osteoblasts, fibroblasts and the epidermis from 15 weeks of gestation [25] and from 30 weeks of gestation it is present in hepatocytes [26]. GH-binding protein (GHBP) levels are

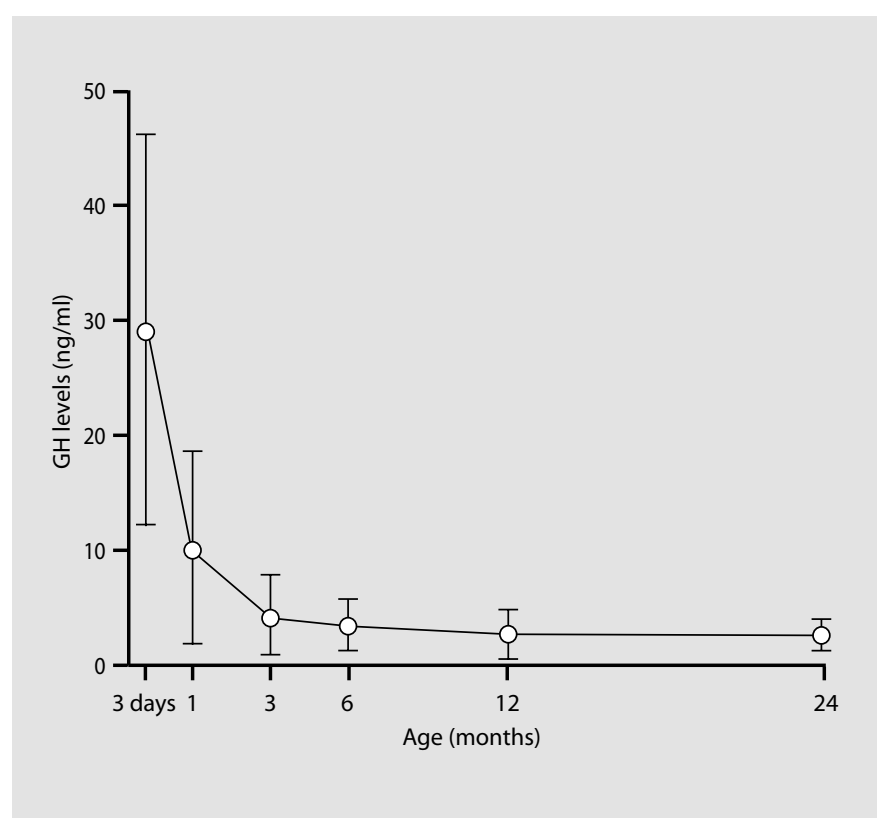

Fig. 1. The pattern of decline in GH levels over the first 2 years of life. Data from Leger et al. [24].

low during fetal life, but are detectable from mid-gestation. Post-natally, GH receptor expression is gradually up-regulated in many tissues [18]. Levels are low in the newborn period with binding levels of around $27 \%$ of those of adults [27]. Levels remain low during the first 3 months of life [28] and rise sharply at 6 months [29], rising thereafter to reach double the neonatal level by 6 years of age [27].

\section{Insulin-Like Growth Factors}

IGF-I and IGF-II are major mediators of pre- and postnatal growth [30-32]. In the mouse, evidence for the role of IGF-I and IGF-II in growth during fetal and early neonatal life comes from transgenic models incorporating disruption of IGF-I, IGF-II and IGF receptor genes [33, 34]. Disruption of either IGF-I or IGF-II production results in severe growth restriction with a $40 \%$ reduction in birth size. Disruption of the IGF-I receptor resulted in greater growth impairment and was uniformly lethal at birth. Animals lacking both the IGF-I and IGF-II receptors had the most severe phenotype (30\% normal size). The data suggest that the fetal growth effects of both IGFI and IGF-II are additive. IGF-I-deficient mice had impaired post-natal growth. In the human, a patient with 
Table 1. Causes of the change in the primary function of GH from a probable metabolic role to a growth-promoting role

Maturation of the hypothalamic-pituitary axis

Secretion of IGF-I becoming GH dependent rather than dependent on nutrition and insulin

Emergence of GH receptors mirrored by an increase in GHBP

Change in the pattern of IGFBPs

a homozygous deletion of the $I G F-I$ gene had severe in utero growth failure that persisted post-natally, providing direct evidence of a GH-independent role for IGF-I in growth both pre- and post-natally [35].

IGF-I levels increase towards term [36, 37] and levels at birth are correlated with gestational age. Although fetal IGF-I levels are low, they correlate with fetal weight and bone length [38, 39]. At birth, there is a relationship between IGF-I levels and birth size that is independent of gestation $[9,31,39-41]$. In the fetus, there is evidence that insulin rather than GH mediates IGF-I production [42]. As the major determinant of fetal growth is substrate availability, the growth-retarded ovine fetus has relatively low levels of IGF-I, irrespective of the cause of the intrauterine growth retardation [42, 43]. Relatively low levels of IGF-I are also found in the growth-retarded human fetus $[36,39]$. At birth, the levels of IGF-I are approximately half of those seen in adults. Levels fall by $25 \%$ on the first day after birth and return toward birth levels by the end of the first week, but remain low for the first 1518 months and rise gradually thereafter [44].

Fetal IGF-II levels increase with gestational age [39, $41,45,46]$, although this finding is not consistent [47]. The levels of IGF-II do not correlate with fetal weight or length $[38,39]$ and the precise role of IGF-II in human growth is unclear.

All six IGF-binding proteins (IGFBP) are widely expressed in fetal tissues [48-51]. The binding proteins modulate IGF action by regulating binding to the type 1 IGF receptor and regulating bioavailability by increasing their half-life. In addition, they regulate tissue distribution and capillary transport.

IGFBP-3 concentrations increase with increasing gestational age [52] with fetal levels being $10-15 \%$ of adult levels. IGFBP-3 levels do not change significantly after birth, but rise slowly over the first 2 years of life [24]. Levels are lower in babies who are small for gestational age (SGA) and higher in babies who are large for gestational age compared with normal babies. In contrast, IGFBP-1 and IGFBP-2 are elevated in SGA babies [44]. IGFBP-1 levels in the fetus are inversely correlated with IGF-I levels and are not elevated in the fetus, which may be important for the normal delivery of IGF-I to the tissues. Umbilical cord blood IGFBP-1 levels correlate inversely with birth size [44, 53]. At birth, IGFBP-1 levels have been reported to be high but variable $[28,46]$, suggesting that IGF-I transport and availability are decreased immediately after birth. This may be important in protecting the newborn from hypoglycaemia. The paradox of low IGF-I levels at a period of maximal human growth may be explained by bioavailability. IGFBP-3 levels in fetal serum are four times lower than in adult serum [52], and the mean molar ratio of [IGF-I] + [IGF-II] to [IGFBP-3] is $50 \%$ higher than in adult serum [52, 54]. In contrast, IGFBP-2 levels in the fetus are elevated three-fold [52]. Hence, relatively more IGF will be bound to the loweraffinity IGFBP-2 molecule (compared with IGFBP-3) with a probable increased bioavailability [52]. The high levels of IGFBP-1 decrease over the first month of life [28]. Normative data for IGF-I, IGFBP-2 and IGFBP-3 from birth through childhood have been published, although there are wide variations between studies [55].

The role of insulin in fetal growth has been clearly identified. Body weight at birth is related to the amount of functioning pancreatic tissue, with hyperinsulinaemic babies being macrosomic and SGA babies having reduced amounts of pancreatic tissue [56]. Insulin may augment fetal growth by influencing production of IGF-I and IGFII $[57,58]$, as well as direct anabolic and growth-promoting effects. Umbilical venous plasma insulin concentration and fetal insulin:glucose ratio increase exponentially with gestation [59]. There is a positive correlation between birthweight and umbilical vein insulin levels [36]. In addition, both the type 1 IGF receptor and insulin receptor share homology, with both ligands able to bind to both receptors. The role of insulin in post-natal growth is unclear, but although it may remain important, nutrition is still a dominant determinant.

In summary, during the first 2 years of life, there is a change in the primary function of $\mathrm{GH}$ from a probable metabolic role to a growth-promoting role. The causes of this change are shown in table 1.

\section{Gene Mutations Resulting in GH Deficiency}

Although the majority of cases of $\mathrm{GH}$ deficiency (GHD) are idiopathic [60], mutations involving the genes of the hypothalamic-pituitary-GH axis may be causative. 
Mutations in the $G H 1$ gene can be transmitted in an autosomal recessive [61] or dominant [62] manner. Mutations of the GHRH receptor gene may also be inherited recessively [63].

Multiple pituitary hormone deficiencies (MPHD) with a genetic basis may result from pituitary activation factors that are involved in the embryonic development of the anterior pituitary gland. An increasing number of patients with MPHD are found to have mutations within pituitary transcription factors PIT1, PROP1 and HESX1 [64]. PIT1 may be inherited dominantly or recessively and is associated with prolactin and thyroid-stimulating hormone (TSH) deficiency, in addition to GHD. Patients with PROP1 defects may also have absent gonadotropin, and reduced cortisol responses to adrenocorticotropic hormone (ACTH) occur in a third of patients [64].

\section{Clinical Presentation of GHD during the First 2 Years of Life}

GHD may be isolated (IGHD) or associated with MPHD. There is an increased incidence of perinatal problems in children who are later diagnosed with idiopathic GHD, in particular those delivered by breech delivery (occurring in 7-65\% of patients with GHD [6568]), or caesarian section, those experiencing prolonged or precipitous deliveries, intrapartum distress or having low Apgar scores at birth $[65,66,69-71]$. These complications are equally frequent in those who have IGHD compared with MPHD [72, 73]. It is not clear whether these adverse events account for the trauma to the pituitary stalk, or whether a developmental anomaly of the hypothalamicpituitary axis predisposes the baby to a breech presentation or the other adverse events.

When presenting in neonates, the most frequent symptom of GHD is severe and persisting hypoglycaemia, which may be associated with convulsions [74, 75]. In boys, there may be micropenis. Babies presenting with GHD within the first $24 \mathrm{~h}$ are often hypothermic (personal observation). Prolonged, conjugated hyperbilirubinaemia may alert a physician to the diagnosis. There are conflicting data regarding whether neonatal symptoms are more frequent in babies with MPHD than in those with IGHD [72, 73]. Dysmorphic features, particularly mid-line defects or craniofacial anomalies, may alert the clinician to dysfunction of the hypothalamic-pituitary axis.

In a review of 1,600 cases of children who were considered for pituitary GH therapy between 1963 and 1984, 29
$(1.8 \%)$ presented under 2 years of age. Of these, 16 presented within the first 6 months, five having IGHD and 11 having MPHD. Eleven of these 16 children presented with symptomatic hypoglycaemia, predominantly within the first $24 \mathrm{~h}$ of life, and 10 of these had MPHD. Four presented with failure to thrive (poor weight gain, but poor length gain detected on review) and one with excessive weight gain at 5 weeks. Of the children presenting between 6 months and 2 years, two had MPHD and 11 had IGHD. One of the two children with MPHD had a hypoglycaemic convulsion at 6 months and the other was diagnosed with failure to thrive and developmental retardation. Of the children with IGHD, all presented with failure to thrive and five of the six boys had microgenitalia [74].

Although it has been believed that children with congenital GHD were of normal size at birth [76, 77] (and from the observation that babies with anencephaly have a normal birth length), the majority of studies since the 1990s have shown that these children have a birth length and weight below the mean, with some children having very severe growth failure even at birth. As the majority of birthweights and lengths are within the normal centiles, however, in the absence of other symptoms these children rarely present at birth. Mean birth length standard deviation scores (SDS) of children later diagnosed with GHD are reported to be +0.4 [78], -0.87 [65], -0.9 [75], -1.3 and -1.7 (depending on subsequent growth patterns [79]) and -2.1 [66]. Weight SDS was higher than length suggesting a degree of adiposity. Profound growth failure may become apparent within the first few months of life. Some children appear to follow the 'infancy' curve of the infancy-childhood-puberty model for the first 6 months of life $[79,80]$, whereas in other children the growth failure is more immediate $[66,78,79,81]$. In 46 children with congenital GHD, for example, Pena-Almazan and colleagues demonstrated a fall in length SDS of 1.6 standard deviations (SD) over the first 6 months of life, with a further fall of 0.6 SD over the second 6 months and a total loss in length of 2.2 SD in the first year. Weight changes over this period were a loss of $0.98 \mathrm{SD}$ in the first 6 months and a further loss of $0.3 \mathrm{SD}$ in the second 6 months [78].

Early growth failure is not universal in children with congenital GHD. For example, children with septo-optic dysplasia or defects in PIT1 or PROP1, may appear to grow normally in early life. The reason for this may be that in those with a hypothalamic defect, the relative paucity of somatostatinergic inhibition of GH secretion results in little impact on growth in the first year. In those 
with PROP1 mutations, the onset of the hormone deficiencies may be delayed, with a median age of diagnosis of GHD in patients with $P R O P 1$ mutations being 6-8 years [82]. PROP1 or PIT1 mutations should be suspected in patients with MPHD particularly when cases are familial, there is consanguinity, or there are reduced pituitary responses to hypothalamic releasing hormones. A molecular diagnosis will aid appropriate hormone replacement strategies and pre-symptomatic diagnosis in other family members.

\section{Diagnosis of GHD}

GH levels (as well as cortisol, ACTH, TSH and thyroxine) should be measured at the time of hypoglycaemia in any baby with severe or symptomatic hypoglycaemia for which another cause is not obvious. Levels of less than $20 \mathrm{ng} / \mathrm{ml}$ would suggest GHD in the newborn [83]. Careful examination may reveal mid-line defects and cerebral ultrasound examination may detect cerebral anomalies that may be associated with septo-optic dysplasia (e.g. absence of the corpus callosum).

In children with growth failure in whom other causes have been excluded, low IGF-I and IGFBP-3 levels may indicate GHD, particularly if levels are below -2 SD. Elevated IGFBP-2 levels may provide additional information [55]. However, these tests are not diagnostic alone.

$\mathrm{GH}$ stimulation tests may be undertaken according to standardized protocols, but insulin tolerance tests are probably not appropriate because clinical signs of severe hypoglycaemia in this age group are not always apparent. Glucagon stimulation tests will also investigate the adrenal axis. Once more, late hypoglycaemia may be profound and should be anticipated, and if this develops, treatment with hydrocortisone in addition to dextrose may be appropriate. Diagnosis of GHD after the neonatal period, when GH levels will have fallen, is made with a GH level of less than $10 \mathrm{ng} / \mathrm{ml}$.

Samples for bone age estimation in children below the age of 1 year are generally taken from the knee and ankle. If the child is over the age of 1 year, the left hand and wrist may be used. In GHD, delay in bone age is typical. In infants presenting with symptoms or signs of MPHD, ophthalmological examination may disclose optic nerve hypoplasia of one or both eyes in children with septooptic dysplasia.

\section{Magnetic Resonance Imaging}

Children diagnosed with GHD during the newborn period have a high incidence of a structural anomaly of the hypothalamic-pituitary region, or septo-optic dysplasia or other brain malformation. In this situation, a magnetic resonance imaging (MRI) scan can aid interpretation of the child's condition. Normally, the anterior pituitary and stalk are well defined, and the posterior pituitary is easily identified as a hyperintense bright spot on unenhanced imaging studies. A small or absent anterior pituitary gland, attenuated or absent pituitary stalk, and an ectopic posterior pituitary gland are all seen in hypopituitarism. In addition, associated cerebral abnormalities including optic nerve hypoplasia, absent septum pellucidum, absent corpus callosum or Chiari I malformation can be identified.

Trauma to the pituitary stalk (e.g. occurring during delivery) will result in a hypoplastic anterior pituitary gland and, with regeneration of the distal axons of the hypothalamus, a superiorly located posterior pituitary gland. Children with congenital GHD whose MRI scans demonstrate pituitary stalk interruption syndrome are likely to have lower GH levels on provocative stimulation, and are more likely to have MPHD, a younger age at diagnosis and neonatal hypoglycaemia [84]. When comparing the scans of children with GHD alone with those of children who have MPHD, children with MPHD are more likely to have a thin, truncated or absent pituitary stalk [85], and an ectopic or absent neurohypophysis, although the position of the posterior pituitary and size of the adenohypophysis is similar between the two groups $[73,85,86]$. When corrected for pubertal status at the time of MRI, one study found that the adenohypophysis was more likely to be small or absent in patients with MPHD [85].

Anterior pituitary size is small or normal in MRI scans in patients with PIT1 mutations. There is no consistent relationship between pituitary size, age of patient or type of mutation [64]. Those with PROP1 mutations also have small or normal anterior pituitary glands. The pituitary stalk is normal and the posterior pituitary is not ectopic. Patients with PROP1 mutations have been reported to show striking enlargement of the anterior pituitary, with suprasellar extension. The anterior pituitary may, in turn, become cystic leaving a near empty sella. 


\section{Conclusions}

GHD may present at birth, usually if there are symptoms other than growth failure, because although children may be short at birth, their lengths are usually within normal limits. Post-natal growth failure may occur early in the months after birth, but in those with a hypothalamic cause of GHD, growth may be preserved. GH levels should be assessed in any baby with severe or symptomatic hypoglycaemia in whom another cause is not obvious. IGF-I and IGFBP levels in infants and babies with suspected GHD should be compared with the normative data for their age.

\section{References}

1 Kaplan S, Grumbach M, Shephard T: The ontogenesis of human fetal hormones. I. Growth hormone and insulin. J Clin Invest 1972;51: 3080-3093.

2 De Zegher F, Kimpen J, Raus J, Vanderschueren-Lodeweyckx $M$ : Hypersomatotropism in the dysmature infant at term and preterm birth. Biol Neonate 1990;58:188-191.

3 Hindmarsh P: Hormonal levels in the human fetus between 14 and 22 weeks gestation. Early Hum Dev 1987;15:253-258.

4 Bassett NS, Gluckman P: Pulsatile growth hormone secretion in the ovine fetus and the neonatal lamb. J Endocrinol 1986;109:307-312.

5 De Zegher F, Bettendorf M, Kaplan S, Grumbach M: Hormone ontogeny in the ovine fetus and neonatal lamb: XXI. Effect of oxogenous insulin-like growth factor I on plasma growth hormone, insulin and glucose concentration. Endocrinology 1988;123:658-660.

6 Wright NM, Northington FJ, Miller JD, Veldhuis JD, Rogol AD: Elevated growth hormone secretory rate in premature infants: deconvolution analysis of pulsatile growth hormone secretion in the neonate. Pediatr Res 1992;32. 286-290.

7 Miller JD, Esparza A, Wright NM, Garimella V, Lai J, Lester SE, Mosier HD Jr: Spontaneous growth hormone release in term infants: changes during the first four days of life. J Clin Endocrinol Metab 1993;76:1058-1062.

8 De Zegher F, Devlieger H, Veldhuis JD: Properties of growth hormone and prolactin hypersecretion by the human infant on the day of birth. J Clin Endocrinol Metab 1993;76:11771181.

9 Ogilvy-Stuart AL, Hands SJ, Adcock CJ, Holly JM, Matthews DR, Mohamed-Ali V, Yudkin JS, Wilkinson AR, Dunger DB: Insulin, insulin-like growth factor I (IGF-I), IGF-binding protein-1, growth hormone, and feeding in the newborn. J Clin Endocrinol Metab 1998;83: 3550-3557.

10 Miller JD, Wright NM, Esparza A, Jansons R, Yang HC, Mosier HD: Spontaneous growth hormone release in male and female premature infants. J Clin Endocrinol Metab 1992;75: 1508-1513.

11 Quabbe HJ, Schilling E, Helge H: Pattern of growth hormone secretion during a 24-hour fast in normal adults. J Clin Endocrinol Metab 1966;2:1173-1177.
12 Takahashi Y, Kipnis DM, Daughaday WH: Growth hormone secretion during sleep. J Clin Invest 1968;47:2079-2090.

13 Vigneri R, D'Agata R: Growth hormone release during the first year of life in relation to sleep-wake periods. J Clin Endocrinol Metab 1971;33:561-563.

14 Shimano S, Suzuki S, Nagashima K, Yagi H, Sakaguchi M, Kuroume T: Growth hormone response to growth hormone releasing factor in neonates. Biol Neonate 1985;47:367-370.

15 Lanes R, Nieto C, Bruguera C, Moncada G, Moret LA, Lifshitz F: Growth hormone-releasing hormone in term and preterm neonates. Biol Neonate 1989;56:252-256.

16 Cuttler L, Welsh JB, Szabo M: The effect of age on somatostatin suppression of basal, growth hormone $(\mathrm{GH})$-releasing factor-stimulated, and dibutyryl adenosine $3^{\prime}, 5^{\prime}$-monophosphatestimulated $\mathrm{GH}$ release from rat pituitary cells in monolayer culture. Endocrinology 1986;119: 152-158.

17 Westphal O: Human growth hormone. A methodological study. Acta Paediatr Scand Suppl 1968;182:63-81.

18 Massa G, De Zegher F, Vanderschueren-Lodeweyckx M: Serum growth hormone-binding proteins in the human fetus and infant. Pediatr Res 1992;32:69-72.

19 Gluckman PD, Breier BH, Oliver M, Harding J, Bassett N: Fetal growth in late gestation - a constrained pattern of growth. Acta Paediatr Scand Suppl 1990;367:105-110.

20 Salardi S, Orsini LF, Cacciari E, Righetti F, Donati S, Mandini M, Cicognani A, Bovicelli L: Growth hormone, insulin-like growth factor I, insulin and C-peptide during human foetal life: in-utero study. Clin Endocrinol 1991;34: 187-190.

21 Adrian TE, Lucas A, Bloom SR, AynsleyGreen A: Growth hormone response to feeding in term and preterm neonates. Acta Paediatr Scand 1983;72:251-254.

22 Fowelin J, Attvall S, von Schenck H, Smith U, Lager I: Characterization of the insulin-antagonistic effect of growth hormone in man. Diabetologia 1991;34:500-506.

23 Cornblath M, Parker ML, Reisner SH, Forbes AE, Daughaday WH: Secretion and metabolism of growth hormone in premature and fullterm infants. J Clin Endocrinol 1965;25:209218
24 Leger J, Noel M, Limal JM, Czernichow P: Growth factors and intrauterine growth retardation. II. Serum growth hormone, insulin-like growth factor (IGF) I, and IGF-binding protein 3 levels in children with intrauterine growth retardation compared with normal control subjects: prospective study from birth to two years of age. Pediatr Res 1996;40:101-107.

25 Werther GA, Haynes K, Waters MJ: Growth hormone $(\mathrm{GH})$ receptors are expressed on human fetal mesenchymal tissues - identification of messenger ribonucleic acid and GH-binding protein. J Clin Endocrinol Metab 1993;76: 1638-1646.

26 Hill DJ, Riley SC, Bassett NS, Waters MJ: Localization of the growth hormone receptor, identified by immunocytochemistry, in second trimester human fetal tissues and in placenta throughout gestation. J Clin Endocrinol Metab 1992;75:646-650.

27 Silbergeld A, Lazar L, Erster B, Keret R, Tepper R, Laron Z: Serum growth hormone binding protein activity in healthy neonates, children and young adults: correlation with age, height and weight. Clin Endocrinol 1989;31: 295-303.

28 Bernardini S, Spadoni GL, Povoa G, Boscherini B, Hall K: Plasma levels of insulin-like growth factor binding protein-1, and growth hormone binding protein activity from birth to the third month of life. Acta Endocrinol 1992; 127:313-318

29 Horikawa R, Tanaka T, Katsumata N, Satoh M, Nagashima A, Watanabe T, Kokai Y, Tanae A, Hibi I: Clinical significance of growth hormone-binding protein measurements in children. Proc Soc Exp Biol Med 1994;206: 320-323.

30 Sara VR, Carlsson-Skwirut C: The biosynthesis of somatomedins and their role in the fetus. Acta Endocrinol Suppl (Copenh) 1986;279:8285.

31 D'Ecole AJ: Somatomedins/insulin-like growth factors and fetal growth. J Dev Physiol 1987;9: 481-495.

32 Milner RDG, Hill DJ: Fetal growth signals Arch Dis Child 1989;64:53-57.

33 Liu J, Baker J, Perkins A, Robertson E, Efstratiadis A: Mice carrying null mutations of the genes encoding insulin-like growth factor I (Igf1) and type I IGF receptor (Igf1r). Cell 1993; 75: 59-72. 
34 Baker J, Liu JP, Robertson EJ, Efstratiadis A: Role of insulin-like growth factors in embryonic and postnatal growth. Cell 1993;75: 73-82.

35 Woods KA, Camacho-Hubner C, Savage MO, Clark AJ: Intrauterine growth retardation and postnatal growth failure associated with deletion of the insulin-like growth factor I gene. N Engl J Med 1996;335:1363-1367.

36 Delmis J, Drazancic A, Ivanisevic M, Suchanek E: Glucose, insulin, HGH and IGF-I levels in maternal serum, amniotic fluid and umbilical venous serum: a comparison between late normal pregnancy and pregnancies complicated with diabetes and fetal growth retardation. J Perinat Med 1992;20:47-56.

37 Barrios V, Argente J, Pozo J, Hervas F, Munoz MT, Sanchez JI, Hernandez M: Insulin-like growth factor I, insulin-like growth factor binding proteins, and growth hormone binding protein in Spanish premature and full-term newborns. Horm Res 1996;46:130-137.

38 Ashton IK, Zapf J, Einschenk I, MacKenzie IZ Insulin-like growth factors (IGF) 1 and 2 in human foetal plasma and relationship to gestational age and foetal size during midpregnancy. Acta Endocrinol 1985;110:558-563.

39 Lassarre C, Hardouin S, Daffos F, Forestier F, Frankenne F, Binoux M: Serum insulin-like growth factors and insulin-like growth factor binding proteins in the human fetus. Relationships with growth in normal subjects and in subjects with intrauterine growth retardation. Pediatr Res 1991;29:219-225.

40 Gluckman PD, Brinsmead MW: Somatomedins in cord blood: relationship to gestational age and birth size. J Clin Endocrinol Metab 1976;43:1378-1381.

41 Bennett A, Wilson DM, Liu F, Nagashima R, Rosenfeld RG, Hintz RL: Levels of insulin-like growth factors I and II in human cord blood. J Clin Endocrinol Metab 1983;57:609-612.

42 Gluckman PD, Butler JH, Comline R, Fowden

A: The effects of pancreatectomy on the plasma concentrations of insulin-like growth factors 1 and 2 in the sheep fetus. J Dev Physiol 1987;9: 79-88.

43 Jones CT, Gu W, Harding JE, Price DA, Parer JT: Studies on the growth of the fetal sheep Effects of surgical reduction in placental size or experimental manipulation of uterine blood flow on plasma sulphation promoting activity and on the concentration of insulin-like growth factors I and II. J Dev Physiol 1988;10:179189.

44 Giudice LC, De Zegher F, Gargosky SE, Dsupin BA, de las Fuentes L, Crystal RA, Hintz RL, Rosenfeld RG: Insulin-like growth factors and their binding proteins in the term and preterm human fetus and neonate with norma and extremes of intrauterine growth. J Clin Endocrinol Metab 1995;80:1548-1555.

45 Samaan NA, Schultz PN, Johnston DA, Creasy RW, Gonik B: Growth hormone, somatomedin $\mathrm{C}$, and nonsuppressible insulin-like activity levels compared in premature, small, average birth weight, and large infants. Am J Obstet Gynecol 1987;157:1524-1528.
46 Verhaeghe J, Van Bree R, Van Herck E, Laureys J, Bouillon R, Van Assche FA: C-peptide, insulin-like growth factors I and II, and insulinlike growth factor binding protein-1 in umbilical cord serum: correlations with birth weight. Am J Obstet Gynecol 1993;169:89-97.

47 Gluckman PD, Johnson-Barrett JJ, Butler JH, Edgar B, Gunn TR: Studies of insulin-like growth factors I and II by specific radioligand assays in umbilical cord blood. Clin Endocrinol 1983;19:405-413.

48 Hill DJ, Clemmons DR, Riley SC, Bassett N, Challis JR: Immunohistochemical localization of insulin-like growth factors (IGFs) and IGF binding proteins- $1,-2$ and -3 in human placenta and fetal membranes. Placenta 1993;14:112.

49 Hill DJ, Clemmons DR: Similar distribution of insulin-like growth factor binding proteins-1, $-2,-3$ in human fetal tissues. Growth Factors 1992;6:315-326.

50 Han VK, Matsell DG, Delhanty PJ, Hill DJ, Shimasaki S, Nygard K: IGF-binding protein mRNAs in the human fetus: tissue and cellular distribution of developmental expression. Horm Res 1996;45:160-166.

51 Delhanty PJ, Hill DJ, Shimasaki S, Han VK: Insulin-like growth factor binding protein-4, -5 and -6 mRNAs in the human fetus: localization to sites of growth and differentiation? Growth Regul 1993;3:8-11.

52 Bang P, Westgren M, Schwander J, Blum WF, Rosenfeld RG, Stangenberg M: Ontogeny of insulin-like growth factor-binding protein-1, -2 , and -3: quantitative measurements by radioimmunoassay in human fetal serum. Pediatr Res 1994;36:528-536.

53 Wang HS, Lim J, English J, Irvine L, Chard T: The concentration of insulin-like growth factor-I and insulin-like growth factor-binding protein-1 in human umbilical cord serum at delivery: relation to fetal weight. $\mathrm{J}$ Endocrinol 1991;129:459-464.

54 Blum WF, Ranke MB, Kietzmann K, Gauggel E, Zeisel HJ, Bierich JR: A specific radioimmunoassay for the growth hormone $(\mathrm{GH})$-dependent somatomedin-binding protein: its use for diagnosis of GH deficiency. J Clin Endocrinol Metab 1990;70:1292-1298.

55 Ranke MB, Schweizer R, Elmlinger MW, Weber K, Binder G, Schwarze CP, Wollmann HA: Significance of basal IGF-I, IGFBP-3 and IGFBP-2 measurements in the diagnostics of short stature in children. Horm Res 2000;54: 60-68.

56 Fowden AL: The role of insulin in prenatal growth. J Dev Physiol 1989;12:173-182.

57 Hill DJ, Milner RDG: Increased somatomedin and cartilage activity in rabbit fetuses injected with insulin in utero. Diabetologia 1980;19: 143-147.

58 Fowden AL: Insulin deficiency: effects on fetal growth and development. J Paediatr Child Health 1993;29:6-11.

59 Economides DL, Nicolaides KH: Metabolic findings in small-for-gestational-age fetuses. Contemp Rev Obstet Gynaecol 1990;2:75-79.
60 Pfaffle R, Blankenstein O, Wuller S, Heimann K, Heimann G: Idiopathic growth hormone deficiency: a vanishing diagnosis? Horm Res 2000;53(suppl 3):1-8.

61 Phillips JA 3rd, Hjelle BL, Seeburg PH, Zachmann M: Molecular basis for familial isolated growth hormone deficiency. Proc Natl Acad Sci USA 1981;78:6372-6375.

62 Binder G, Keller E, Mix M, Massa GG, Stokvis-Brantsma WH, Wit JM, Ranke MB: Isolated GH deficiency with dominant inheritance: new mutations, new insights. J Clin Endocrinol Metab 2001;86:3877-3881.

63 Wajnrajch MP, Gertner JM, Harbison MD Chua SC Jr, Leibel RL: Nonsense mutation in the human growth hormone-releasing hormone receptor causes growth failure analogous to the little (lit) mouse. Nat Genet 1996;12:88-90.

64 Parks JS, Brown MR, Hurley DL, Phelps CJ, Wajnrajch MP: Heritable disorders of pituitary development. J Clin Endocrinol Metab 1999; $84: 4362-4370$

65 Albertsson-Wikland K, Niklasson A, Karlberg P: Birth data for patients who later develop growth hormone deficiency: preliminary analysis of a national register. The Executive Scientific Committee of the Kabi International Growth Study and the Swedish Paediatric Study Group for Growth Hormone Treatment. Acta Paediatr Scand Suppl 1990;370:115-120.

66 De Luca F, Bernasconi S, Blandino A, Cavallo L, Cisternino M: Auxological, clinical and neuroradiological findings in infants with early onset growth hormone deficiency. Acta Paediatr 1995;84:561-565.

67 Goodman HG, Grumbach MM, Kaplan SL: Growth and growth hormone. II. A comparison of isolated growth-hormone deficiency and multiple pituitary-hormone deficiencies in 35 patients with idiopathic hypopituitary dwarfism. N Engl J Med 1968;278:57-68.

68 Beirich JR: On the aetiology of hypopituitary dwarfism; in Pecile A, Muller EE (eds): Growth and Growth Hormone. Proceedings of the 2nd International Symposium on Growth Hormone. Amsterdam, Excerpta Medica Foundation, 1972.

69 Craft WH, Underwood LE, Van Wyk JJ: High incidence of perinatal insult in children with idiopathic hypopituitarism. J Pediatr 1980;96: 397-402.

70 Maghnie M, Larizza D, Triulzi F, Sampaolo P, Scotti G, Severi F: Hypopituitarism and stalk agenesis: a congenital syndrome worsened by breech delivery? Horm Res 1991;35:104-108.

71 Van den Broeck J, Vanderschueren-Lodeweyckx M, Malvaux P, Craen M, Van Vliet G, Dooms L, Eggermont E: Growth hormone deficiency: a hidden obstetrical trauma? Eur J Obstet Gynecol Reprod Biol 1987;26:329-334.

72 Pinto G, Netchine I, Sobrier ML, Brunelle F, Souberbielle JC, Brauner R: Pituitary stalk interruption syndrome: a clinical-biological-genetic assessment of its pathogenesis. J Clin Endocrinol Metab 1997;82:3450-3454.

73 Hamilton J, Blaser S, Daneman D: MR imaging in idiopathic growth hormone deficiency. AJNR Am J Neuroradiol 1998;19:1609-1615. 
74 Herber SM, Milner RD: Growth hormone deficiency presenting under age 2 years. Arch Dis Child 1984;59:557-560.

75 Huet F, Carel J-C, Nivelon J-L, Chaussain J-L: Long-term results of GH therapy in GH-deficient children treated before 1 year of age. Eur J Endocrinol 1999;140:29-34.

76 Falkner F, Tanner JM (eds): Human growth. Vol 1: Developmental Biology; Prenatal Growth, 2nd ed. New York, Plenum Press, 1986.

77 Laron Z, Pertzelan A: Somatotrophin in antenatal and perinatal growth and development. Lancet 1969;1(7596):680-681.

78 Pena-Almazan S, Buchlis J, Miller S, Shine B, MacGillivray M: Linear growth characteristics of congenitally $\mathrm{GH}$-deficient infants from birth to one year of age. J Clin Endocrinol Metab 2001;86:5691-5694.
79 Wit JM, van Unen H: Growth of infants with neonatal growth hormone deficiency. Arch Dis Child 1992;67:920-924.

80 Karlberg J, Albertsson-Wikland K: Infancy growth pattern related to growth hormone deficiency. Acta Paediatr Scand 1988;77:385-391.

81 Chatelain P: Dramatic early postnatal growth failure in children with early onset growth hormone deficiency. Acta Paediatr Scand Suppl 1991;379:100-102.

82 Parks JS: The ontogeny of growth hormone sensitivity. Horm Res 2001;55(suppl 2):27-31.

83 Consensus guidelines for the diagnosis and treatment of growth hormone $(\mathrm{GH})$ deficiency in childhood and adolescence: summary statement of the GH Research Society. GH Research Society. J Clin Endocrinol Metab 2000; 85:3990-3993.
84 Arrigo T, De Luca F, Maghnie M, Blandino A, Lombardo F, Messina MF, Wasniewska M, Ghizzoni L, Bozzola M: Relationships between neuroradiological and clinical features in apparently idiopathic hypopituitarism. Eur J Endocrinol 1998;139:84-88.

85 Kornreich L, Horev G, Lazar L, Schwarz M, Sulkes J, Pertzelan A: MR findings in growth hormone deficiency: correlation with severity of hypopituitarism. AJNR Am J Neuroradiol 1998;19:1495-1499.

86 Bozzola M, Mengarda F, Sartirana P, Tato L, Chaussain JL: Long-term follow-up evaluation of magnetic resonance imaging in the prognosis of permanent GH deficiency. Eur J Endocrinol 2000;143:493-496. 